\title{
Molecular characterization of a bacterial consortium enriched from an oilfield that degrades phenanthrene
}

\author{
Zhenyu Wang ${ }^{1,2}$, Jing Zhang ${ }^{1}$, Yu Zhang ${ }^{1}$, Abdel Latif Hesham ${ }^{1}$ \& Min Yang ${ }^{1, *}$ \\ ${ }^{1}$ State Key Laboratory of Environmental Aquatic Chemistry, Research Center for Eco-Environmental \\ Sciences, Chinese Academy of Sciences, P.O. Box 2871, Beijing 100085, P.R. China \\ ${ }^{2}$ College of Life Science, Henan Normal University, Xinxiang Henan 453007, P.R. China \\ *Author for correspondence (Fax: +86-10-62923475; E-mail: yangmin@rcees.ac.cn)
}

Received 7 December 2005; Revisions requested 15 December 2005; Revisions received 23 January 2006; Accepted 23 January 2006

Key words: biodegradation, catabolic gene, cloning, phenanthrene

\begin{abstract}
Characterization of functional and phylogenetic genes was carried out on a bacterial consortium, enriched from a water treatment system of an oilfield, that could use phenanthrene as the sole carbon source. The mixed culture degraded $130 \mathrm{mg}$ phenanthrene $1^{-1}$ in 16 days, which is significantly faster than previously reported pure cultures. The existence of catabolic genes $(\mathrm{nahAc}, \mathrm{C23O})$ in the mixed culture was quantitated by most probable number PCR. The plasmid encoding phenanthrene catabolic genes increased relative to the chromosome genes. Heterogeneous bacteria were present according to both PCR denaturing gradient gel electrophoresis and cloning methods, suggesting the possible existence of cooperation between different biochemical PAH-transforming pathways.
\end{abstract}

\section{Introduction}

Many microbes with the ability to degrade polycyclic aromatic hydrocarbons (PAHs) have been isolated and PAH degradation mechanisms, enzymes and genes have been widely studied using these isolates (Tuomi et al. 2004). However, PAH biodegradation by pure cultures may not represent the actual behavior of environmental microbes since the cooperation of indigenous strains is damaged. Ghazali et al. (2004) constructed a microbial consortium by mixing together several known strains to degrade hydrocarbons. However, it is difficult to maximize cooperation among different species using a synthetic microbial consortium, and a more reasonable way to acquire an efficient degradation system would be by enriching microbes from environments using the target compounds as the carbon source.

In this study, an enriched culture system for phenanthrene degradation was acquired from the aerobic sludge of a water treatment plant within an oilfield. The consortium was analyzed by both PCR denaturing gradient gel electrophoresis and a cloning method. Changes of phenanthrene degradation genes, including naphthelene-2,3-dioxygenase (nahAc) and catachol-2,3-dioxygenase (C23O) that are responsible for the biotransformation of naphthalene and phenanthrene, were followed using most probable number PCR.

\section{Materials and methods}

\section{Selective culture}

The minimal basal salt (MBS) medium used in this study contained, per liter of water, $1000 \mathrm{mg}$ $\left(\mathrm{NH}_{4}\right)_{2} \mathrm{SO}_{4}, 800 \mathrm{mg} \mathrm{K}{ }_{2} \mathrm{HPO}_{4}, 200 \mathrm{mg} \mathrm{K \textrm {K } _ { 2 }} \mathrm{PO}_{4}$, $200 \mathrm{mg} \quad \mathrm{MgSO}_{4} \cdot 7 \mathrm{H}_{2} \mathrm{O}, 100 \mathrm{mg} \quad \mathrm{CaCl}_{2} \cdot 2 \mathrm{H}_{2} \mathrm{O}$, $5 \mathrm{mg} \mathrm{FeSO}{ }_{4} \cdot 7 \mathrm{H}_{2} \mathrm{O}$, and $1 \mathrm{ml}$ of vitamin solution (Zhang \& Young 1997). The culture was carried 
out at $150 \mathrm{rpm}$ and $37^{\circ} \mathrm{C}$ for 20 days with $10 \mathrm{mg}$ phenanthrene as the sole carbon source in $100 \mathrm{ml}$ MBS medium.

\section{Phenanthrene degradation and analysis}

Degradation was performed in flasks containing $100 \mathrm{ml}$ MBS medium and $13 \mathrm{mg}$ phenanthrene after inoculation of $1 \mathrm{ml}$ fresh culture $\left(10^{4}\right.$ copies of 16S rDNA). Heat-killed cells (autoclaved) and non-inoculated flasks were used as negative and blank controls, respectively. Cultures were grown in the dark with shaking at $150 \mathrm{rpm}$ and $37{ }^{\circ} \mathrm{C}$. A series of identical vessels, in triplet, were taken for analysis at given times.

The samples were extracted twice by $100 \mathrm{ml}$ hexane. After being concentrated to dryness under a gentle flow of $\mathrm{N}_{2}$, the extracts were dissolved in an appropriate amount of hexane and analyzed in duplicate by GC/MS using an Agilent 6890 GC equipped with an HP-5 MS column (Gabriel et al. 2005). For the extraction, the recovery of the external standard ranged from 92 to $100 \%$, with a mean value of $96 \%$ and a relative standard deviation of $4 \%$.

\section{$D N A$ extraction and most probable number-PCR} (MPN-PCR)

One milliliter culture was taken for genomic and plasmid DNA extraction using the Unix-10 column DNA Preps Kit (Sangon, China) and EZ-10 Spin column Plasmid Mini-preps Kit (BBI, Canada) following the manufacturer's instructions, respectively.
Both DNA extracts were serially diluted 10fold, and three samples of each dilution were subjected to PCR. The PCR primers are shown in Table 1. The programs of PCR were optimized as follows: first denaturation was carried out at $94{ }^{\circ} \mathrm{C}$ for $4 \mathrm{~min}$, then 40 cycles were completed with denaturation at $94{ }^{\circ} \mathrm{C}$ for $40 \mathrm{~s}$. Annealing was performed at $60^{\circ} \mathrm{C}$ for $E U B$ and $C 23 O$ genes, $54{ }^{\circ} \mathrm{C}$ for $n a h A c$ and $55{ }^{\circ} \mathrm{C}$ for $E U B$-GC clamp. Elongation was conducted at $72{ }^{\circ} \mathrm{C}$ for $40 \mathrm{~s}$ and a final elongation occurred at $72{ }^{\circ} \mathrm{C}$ for $10 \mathrm{~min}$.

\section{$D G G E$ and cloning of $16 S$ rDNA}

The V3 region of the 16S rRNA gene was amplified from genomic DNA, and provided for DGGE analysis on a Bio-Rad Dcode system (Muyzer et al. 1993). For cloning, another pair of primers (Holger et al. 1997) was used to amplify the 16S rRNA gene with a different final extension at $72{ }^{\circ} \mathrm{C}$ for $30 \mathrm{~min}$. T/A cloning and blue/ white screening were conducted using a T-vector PCR product clone Kit (Sangon, Shanghai). After restriction enzyme analysis, foreign fragments with a unique profile were sequenced.

\section{Results and discussion}

Phenanthrene degradation and cell growth

As shown in Figure 1, $130 \mathrm{mg}$ phenanthrene $1^{-1}$ was degraded by the mixed culture of bacteria to $0.013 \mathrm{mg} \mathrm{l}^{-1}$ within 16 days. This was higher

Table 1. Primers used in this study.

\begin{tabular}{|c|c|c|c|c|}
\hline Primer & Target & Sequence $\left(5^{\prime}-3^{\prime}\right)$ & Expected size (bp) & Reference \\
\hline$E U B F$ & 16s rDNA & GCACAAGCGGTGGAGCATGTGG & & \\
\hline$E U B R$ & & GCCCGGGAACGTATTCACCG & 455 & Iwamoto et al. (2000) \\
\hline$E U B 341 F^{\mathrm{a}}$ & 16s rDNA & GCCCGGGAACGTATTCACCG & & \\
\hline EUB518R & & ATTACCGCGGCTGCTGG & 230 & Muyzer et al. (1993) \\
\hline$F 27$ & 16s rDNA & AGAGTTTGATC(A/C)TGGCTCAG & & \\
\hline R1378 & & CGGTGTGTACAAGGCCCGGGAACG & 1374 & Holger et al. (1997) \\
\hline$n a h A c F$ & nahAc & TGGCGATGAAGAACTTTTCC & & \\
\hline $\operatorname{nahAcR}$ & & AACGTACGCTGAACCGAGTC & 992 & Laurie \& Jones (2000) \\
\hline $\mathrm{C} 23 \mathrm{OF}$ & $\mathrm{C} 23 \mathrm{O}$ & AAGAGGCATGGGGGCGCACCGGTTCGATCA & & \\
\hline $\mathrm{C} 23 \mathrm{OR}$ & & CCAGCAAACACCTCGTTGCGGTTGCC & 377 & Sei et al. (2004) \\
\hline
\end{tabular}

The target gene of $E U B$ and $E U B$-GC is 16s rDNA.

GC-clamp: CGC CCG CCG CGC CCC GCG CCC GTC CCG CCG CCC CCG CCC G was attached to EUB341F. 
than the rate achieved by Pseudomonas aeruginosa, which degraded $100 \mathrm{mg}$ phenanthrene $1^{-1}$ to $0.2 \mathrm{mg}^{-1}$ in 30 days (Romero et al. 1998). During the degradation, the cell mass in terms of DNA copies increased from $10^{4}$ copies $\mathrm{ml}^{-1}$ to about $10^{8}$ copies $\mathrm{ml}^{-1}$.

\section{Variations of target catabolic genes}

Figure 2 shows that both nahAc and $C 23 O$ encoded, respectively, by plasmid and chromosome existed in the mixed culture. However, the number of copies of the plasmid encoding genes increased with the degradation of phenanthrene while the

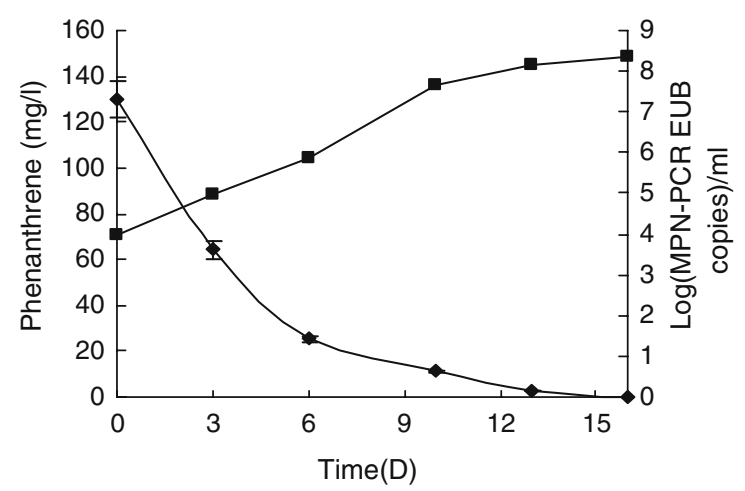

Fig. 1. Phenanthrene degradation and cell growth. Phenanthrene concentration was detected by GC-MS. The number of 16S rDNA copies was used to indicate the cell mass. ( $\downarrow)$ concentration of phenanthrene; ( $\bullet$ copies of 16S rDNA (EUB).

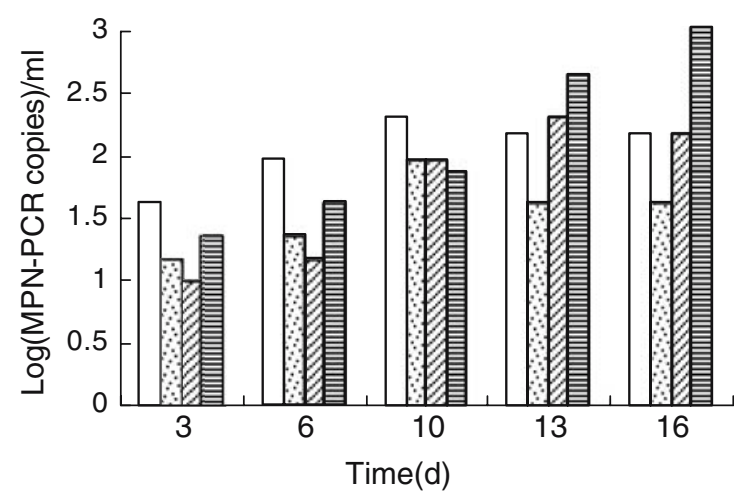

Fig. 2. Changes of the catabolic genes during phenanthrene degradation. The copies of $n a h A c$ and $C 23 O$ encoded by chromosome and plasmid, respectively, were quantified using

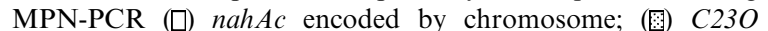
encoding by chromosome; (E) nahAc encoded by plasmid; (티) $\mathrm{C} 23 \mathrm{O}$ encoded by plasmid. number of chromosome encoding genes stayed almost unchanged. As shown in Figure 3, the number of copies of plasmid encoding catabolic genes relative to each DNA copy increased during degradation of phenanthrene, suggesting the increase of plasmid numbers in each bacterial cell. The catabolic genes harbored by a plasmid can be transferred to other bacteria, even taxonomically divergent hosts in the environment, and function well (Bhadbhade et al. 2002). This indicates that plasmid-mediated bioaugmentation might be a possible strategy, especially for systems not suitable for the survival of isolated bacteria.

\section{Biodiversity of genotypes}

Heterogeneous diversity of the consortium was studied by both PCR-DGGE and 16S rDNA cloning methods, and the sequencing results are shown in Table 2, which indicate the existence of bacteria of different genera in the consortium. Compared to the sequencing results of DGGE bands, cloning gave a more decisive result. Among the 7 clones sequenced, three clones belonged to Sphingomonas sp., two to Burkholderia sp., and one to Pandoraea pnomenusa. Chiara et al. (2004) reported that Pseudomonas sp. encodes the $n a h$-homologous pathway (salicylatecatechol formation), while Burkholderia sp. encodes a phn-homologous pathway (phthalateprotocatechuate formation) during the degradation of phenanthrene. The existence of three species of Sphingomonas and Pandoraea pnomenusa indicates that phenanthrene might also be metabolized through other pathways. The cooperation among diverse genotype bacteria and possible plural degradation pathways might be the main reasons for the fast degradation of phenanthrene by the consortium. Furthermore, such a biological system should be stable since the ecological relationship among native microbes could be maintained. So a consortium enriched from environment is more applicable than pure culture for pollutant removal.

\section{Conclusions}

Different species and genera in the consortium with different pathways performed well in 

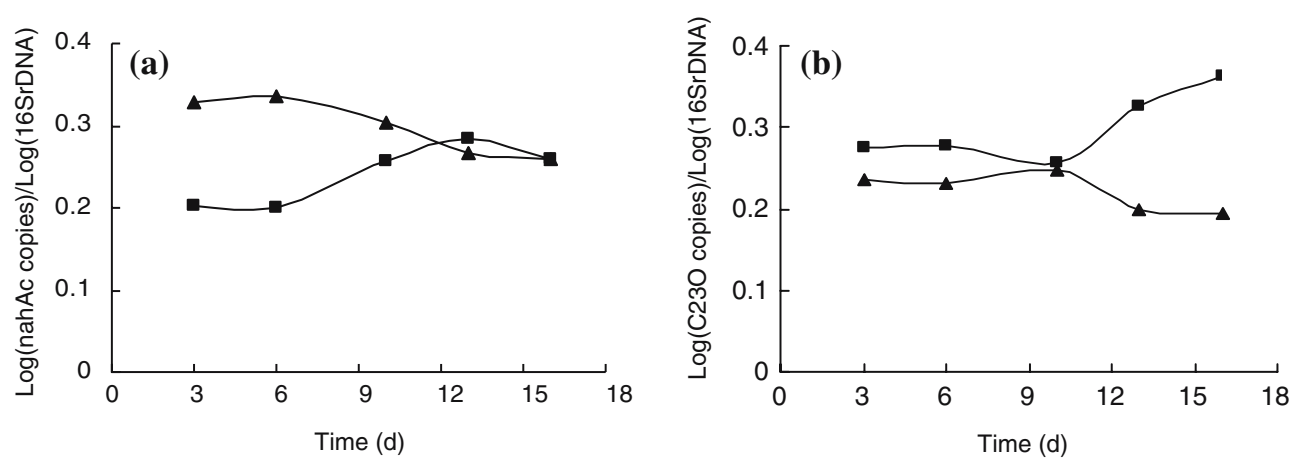

Fig. 3. Relative ratios of catabolic genes to EUB during phenanthrene degradation. The ratios were obtained by dividing the logarithm of catabolic gene copies by the logarithm of EUB copies. (a) nahAc; (b) C23O. ( ) chromosome; (অ) plasmid.

Table 2. Genotype diversity in the consortium.

\begin{tabular}{llllll}
\hline Highest similarity (DGGE) & Homology $^{\mathrm{a}}(\%)$ & Acces. No. $^{\text {b }}$ & Highest similarity (clone) & Homology (\%) & Acces. No. \\
\hline Uncultured bacterium & 97 & DQ225130 & Burkholderia sp. & 99 & DQ256752 \\
Uncultured Pseudomonas sp. & 98 & DQ225131 & Pandoraea pnomenusa & 99 & DQ256753 \\
Uncultured bacterium & 97 & DQ225132 & Sphingomonas sp. A24 & 97 & DQ256754 \\
Uncultured bacterium & 98 & DQ225133 & Burkholderia sp. B7 & 99 & DQ256755 \\
Uncultured bacterium & 96 & DQ225134 & Uncultured sphingobium sp. B14 & 97 & DQ256756 \\
Uncultured Dyella sp. & 96 & DQ225135 & Uncultured sphingomonas sp. B22 & 98 & DQ256757 \\
Uncultured bacterium & 95 & DQ225136 & Uncultured bacterium clone B9 & 98 & DQ256758 \\
Uncultured Pseudomonas sp. & 98 & DQ225137 & & & \\
\hline
\end{tabular}

The left part is the sequencing results of DGGE and the right is the sequencing results of cloning.

${ }^{a}$ Homology was the result of BLAST in Genbank.

${ }^{\mathrm{b}}$ The Accession No. for Genbank.

phenanthrene degradation, indicating that the coexistence and cooperation of indigenous bacteria might promote phenanthrene degradation. The catabolic genes harbored by the plasmid contributed more than those by the chromosome to the degradation of phenanthrene.

\section{Acknowledgements}

This study was supported by the National Basic Research Program of China (No. 2003CB415006) and the National Natural Science Foundation of China (No. 20337020, 50578153).

\section{References}

Bhadbhade BJ, Dhakephalkar PK, Sarnaik SS, Kanekar PP (2002) Plasmid-associated biodegradation of an organophosphorus pesticide, Monocrotophos, by Pseudomonas mendocina. Biotechnol. Lett. 24: 647-650.
Chiara Z, Simona DG, Filippo V, Giovanni V (2004) Biodiversity amongst cultivable polycyclic aromatic hydrocarbontransforming bacteria isolated from an abandoned industrial site. FEMS Microbiol. Lett. 238: 375-382.

Gabriel FLP, Giger W, Guenther K, Kohler HE (2005) Differential degradation of nonylphenol isomers by Sphingomanas xenophaga Bayram. Appl. Envrion. Microbiol. 71: 1123-1129.

Ghazali FM, Rahman RNZA, Salleh AB, Basri M (2004) Biodegradation of hydrocarbons in soil by microbial consortium. Int. Biodeter. Biodegr. 54: 61-67.

Holger H, Martin K, Paul B, Kornelia S, Elizabeth MHW (1997) Analysis of actinomycete communities by specific amplification of genes encoding 16S rRNA and gel-electrophoretic separation in denaturing gradients. Appl. Environ. Microbiol. 63: 3233-3241.

Iwamoto T, Tani K, Nakamura K, Suzuki Y, Kitagawa M, Eguchi M, Nasu M (2000) Monitoring impact of in situ biostimulation treatment on groundwater bacterial community by DGGE. FEMS Microbiol. Ecol. 32: 129-141.

Laurie AD, Jones G (2000) Quantification of phnAc and nahAc in contaminated New Zealand soils by competitive PCR. Appl. Environ. Microbiol. 66: 1814-1817.

Muyzer G, Waal EC, Uitterlinden AG (1993) Profiling of complex microbial populations by denaturing gradient gel electrophoresis analysis of polymerase chain reaction- 
amplified genes coding for 16S rRNA. Appl. Environ. Microbiol. 59: 695-700.

Romero MC, Cazau MC, Giorgieri S, Arambarri AM (1998) Phenanthrene degradation by microorganisms isolated from a contaminated stream. Environ. Pollut. 101: 355-359.

Sei K, Inoue D, Wada K, Mori K, Ike M, Kohno T, Fujita M (2004) Monitoring behaviour of catabolic genes and change of microbial community structures in seawater microcosms during aromatic compound degradation. Wat. Res. 38: 4405-4414.
Tuomi PM, Salminen JM, Jorensen KS (2004) The abundance of nahAc genes correlates with the ${ }^{14} \mathrm{C}$-naphthalene mineralization potential in petroleum hydrocarbon-contaminated oxic soil layers. FEMS Microbiol. Ecol. 51: 99-107.

Zhang XM, Young LY (1997) Carboxylation as an initial reaction in the anaerobic metabolism of naphthalene and phenanthrene by sulfidogenic consortia. Appl. Environ. Microbiol. 63: 4759-4764. 